\title{
DEVELOPMENT AND \\ DEMOCRATIZATION
}

Carles Boix

$2009 / 26$

\begin{tabular}{|l|l|}
\hline I & B \\
\hline E & I \\
\hline
\end{tabular}

INSTITUT

B
BA'ESTUDIS
INTRNACONALS

\section{Carles Boix}

Princeton University / Institut Barcelona d'Estudis Internacionals cboix@princeton.edu 
IBEI WORKING PAPERS

$2009 / 26$

Development and Democratization

(C) Carles Boix

(C) IBEI, de esta edición

$\begin{array}{ll}\text { Edita: } & \text { CIDOB edicions } \\ & \text { Elisabets, } 12 \\ & 08001 \text { Barcelona } \\ \text { Tel. } 933026495 \\ \text { Fax. } 933022118 \\ \text { E-mail: publicaciones@cidob.org } \\ \text { URL: www.cidob.org }\end{array}$

Depósito legal: B-21.147-2006

ISSN:1886-2802

Imprime: Color Marfil, S.L.

Barcelona, November 2009 


\title{
DEVELOPMENT AND DEMOCRATIZATION
}

\author{
Carles Boix
}

Abstract: Current studies, mainly focused on the postwar period, are split on the impact of development on democracy. Examining panel data that runs from early nineteenth century (a time where hardly any democracy was in place) to the end of the twentieth century, I show income matters positively for democratization - both after controlling for country and time effects and instrumenting for income. Since the effect of time partly varies over time, with some historical periods that are more favorable to democracy than others, I investigate the domestic variables (a decreasing marginal effect of growth in already developed economies) and international factors (the strategies of great powers toward small countries) generating that result. I finally probe the underlying processes through which income shapes political institutions, showing that development produces key changes in the distribution and nature of wealth that, in turn, make democracy a stable political outcome.

Key words: Democracy, Development, Income, Political Transitions, International Relations

Acknowledgements: I thank the comments of Robert Keohane, Elena Nikolova, Gerad Padró and Susan Stokes. I am also grateful for the research support of Raymond Hicks at the Niehaus Center for Globalization and Governance. 


\section{Introduction}

Since the publication of Seymour Lipset's influential article on "Some Social Requisites of Democracy" fifty years ago (Lipset 1959), the research agenda on democratization has been dominated by a prolonged debate over the impact of economic development on political institutions. On the one hand, most researchers have found that higher levels of development (mainly measured through per capita income) increase either the likelihood of democratic transitions or the stability of democracies (Dahl 1971; Huntington 1991; Przeworski and Limongi 1997; Barro 1999; Boix and Stokes 2003). On the other hand, an important sociological literature has questioned that relationship and attributed the presence of democratic institutions to either particular historical conjectures in early modern Europe (Moore 1966) or to the choices of military and bureaucratic elites in Latin America (O'Donnell 1973). More recently, Acemoglu et al. (2008) employ systematic econometric tests to conclude that economic development (proxied by the level of per capita income) has no effect on the likelihood of a country becoming (and staying) democratic - mainly for the period after World War II. Mostly following Moore (1966), they then trace the roots of democracy (as well as the causes of economic development) back to critical historical junctures that took place about five hundred years ago and that pushed societies into divergent political and economic paths. In a nutshell, democracy and development, although strongly correlated nowadays, are at most simple covariates.

In this article I examine again the relationship between development and democracy, employing the estimating strategies of Acemoglu et al. (2008) (who include fixed country- and year- effects and instrumental variables), for the last two centuries. The analysis of such a long span of time, from a point of time in which there were no democracies in place to current times, shows that development matters both to spur democratic transitions and to consolidate existing democracies.

This article is organized as follows. After briefly summarizing the state of the empirical literature on the causes of democratization (Section 1), I discuss how the choice of a particular historical period, such as the years after World War Two, to study the impact of development on democracy necessarily shapes the size and statistical significance of the estimates of the variable of interest (in this case, income) (Section 2). In particular, I show that those recent studies, such as Przeworksi and Limongi (1997) and Acemoglu et al. (2008), that find no causal effect of development (proxied by income per capita) on democratization, do not precisely because they use empirical evidence mainly limited to the post-WWII period. Their main panel data set, which spans from 1950 to 1990 (in Przeworski and Limongi 1997) or from 1960 to 2000 (in Acemoglu et al. 2008), cannot capture key phases in the process of democratization across the world - what Huntington (1991) referred to as the first and second waves of democratization. (Although Acemoglu et al. (2008) include an additional (short) test employing data from 1875 to 2000, that analysis faces considerable limitations due to the rather reduced number of countries and of time-periods it includes.) Accordingly, in Section 3 I re-estimate the relationship for all the data from the early nineteenth century (a time where almost all countries were not democratic) to the end of the twentieth century, using the same estimation strategies of Acemoglu et al. 
(2008), and I find that development matters for democratization - although the effect partly varies over time, with some historical periods that are more favorable to democracy than others. Given those results, in Section 4 I investigate the domestic variables (such as the decreasing marginal effects of growth in already developed economies) and international factors (the strategies of great powers toward small countries) that may account for the varying effects of income on democracy over time. Finally, in Section 5 I discuss the theoretical underpinnings behind those empirical results - mostly following and qualifying an extensive debate in the literature (Boix 2003; Boix and Stokes 2003; Acemoglu et al. 2006; Geddes 2007, Inglehart 2007) - and I probe empirically the underlying causes, such as inequality, human capital formation or asset specificity, that drive the twin processes of democratic transition and consolidation, and that the literature has so far proxied through income per capita.

\section{State of the Literature}

In the last decades a substantial part of the research agenda on the causes of democracy has been shaped by the so-called modernization theory of democratization. Broadly speaking, modernization theory claims that economic development (often proxied by the national level of per capita income) triggers the process of democratization. This rather narrow empirical proposition was first suggested by Lipset (1959) and then received at least partial support in two distinctive forms. Most researchers claimed that the likelihood of transitions to democracy increases among richer countries (Dahl 1971; Huntington 1991; Barro 1999; Boix and Stokes 2003; Epstein et al. 2006). Other scholars limited the role of development to having a strict stabilization effect on democracy once the latter has come into place for reasons, such as war defeats or the natural death of dictators, which are mainly exogenous to income (Przeworski and Limongi 1997). As I examine in the last section of this paper, the potential theoretical interpretation of that finding has been, by contrast, more contentious: income has alternatively been seen as a proxy for changes in the social structure and in the distribution of income, for a growth of toleration values or for the declining marginal disutility on high incomes of public transfers associated with democracies (Lipset 1957; Przeworski et al. 2000; Boix and Stokes 2003, Boix 2003).

By contrast, and following in the steps of Moore (1966), but employing systematic econometric tests, Acemoglu et al. (2008) make two key claims: first, that existing empirical tests, mostly based on cross-country relationships, cannot establish causality from income to democracy; and, second, that, since those empirical studies do not control for country-specific factors affecting both income and democracy, they may be strongly affected by omitted-variable bias. Once Acemoglu et al. (2008) include country fixed effects (as well as year dummies) in their econometric estimations, the positive relationship between per capita income and political regime fades away. Moreover, the additional instrumentation of income seems to discard any potential causal effect of income on democracy. 


\section{The Question of Data Specification}

Nearly all modernization scholars have examined the relationship between income and democracy during the postwar period. And, as Acemoglu et al. (2008) recently stress, a simple graphical examination of the relationship (in Figures 2 and 3 of their article) already seems to dispel the notion that income growth leads to more democracy: changes in income cannot be correlated with changes in political institutions during the period after 1960. As noted above, the battery of economic tests with country and time dummies they conduct subsequently conveys the same result.

\section{Figure 1. The Evolution of Democracies, 1800-2000}

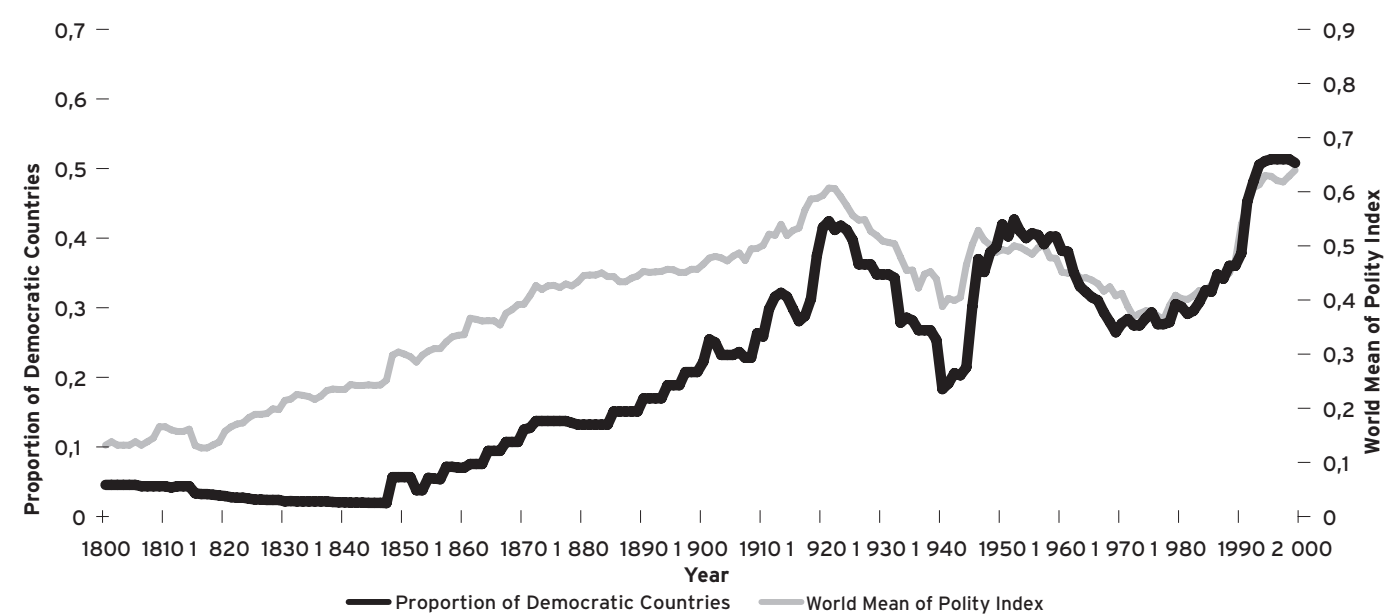

The problem of any study circumscribed to the period after World War Two is, however, that it cannot convincingly establish what may generate the transition to democracy because it excludes a key part of the process of political development at work before 1940. To see why, Figure 1 reports the evolution of democracy among sovereign countries from 1800 to 2000 using two measures: first, the annual proportion of democracies, where a country is defined as democratic if it has a government elected through competitive elections and liberal franchise requirements, as coded in Boix and Rosato (2001); ${ }^{1}$ second, the cross-national average of the polity index taken from Polity IV and normalized into a continuous variable from 0 (no democracy) to 1 (full democracy).

Two main facts are already apparent in Figure 1. In the first place, democracy was a rather stable phenomenon across countries between 1960 and 1990. The proportion of democratic countries hardly changed, mainly fluctuating between 30 to 40 percent. In

1. The Boix-Rosato measure defined a country as democratic if it meets three criteria: elections are free and competitive, the executive is accountable to citizens (either through elections in presidential elections or to the legislature in parliamentary systems) and at least half of the male electorate is enfranchised. 
fact, only a few countries moved in and out of democracy --particularly in Latin America. Table 1 shows that the bulk of those nations (45 out of 53) that were democratic in 1960 remained democratic three decades later. Among those eight cases where democracy broke down, five countries (four African states and Singapore) became authoritarian within the first four years following independence and an additional two within eight years after they became independent. Similarly, authoritarian institutions were remarkably stable: most of those countries (54 out of 70) that were not democratic at the beginning of the period were still under authoritarian rule in 1990. Among those 16 that shifted to democracy, five did directly after the collapse of the Soviet Union.

\begin{tabular}{|c|c|c|c|}
\hline & & \multicolumn{2}{|c|}{ Number of countries in 1990} \\
\hline & & Authoritarian & Democratic \\
\hline \multirow{2}{*}{$\begin{array}{l}\text { Number of countries in } 1960 \\
\text { or at the time of independence }\end{array}$} & Democratic & 8 & 45 \\
\hline & Authoritarian & 54 & 16 \\
\hline
\end{tabular}

In the second place, Figure 1 makes clear that most of the significant (and, in fact, lasting) political change, that is, the first democratization wave, occurred before 1945: partly in the nineteenth century and then right after World War One. A second, shorter wave happened right after 1945 and before 1960. Hence, excluding pre-1960 data (while controlling for country effects) risks misestimating the true effects of economic and social change on political institutions since there was little within-country variance from 1960 well into the mid 1990s. To put it differently, the empirical problem at hand carries considerable resemblance to similar questions in empirical growth theory. Although only employing postwar data sets may be good enough to estimate convergence effects (among economies that have moved beyond the take-off stage), it is not adequate enough to determine the sources of initial divergence across countries.

\section{Figure 2. Level of Economic Development, 1850-2000}

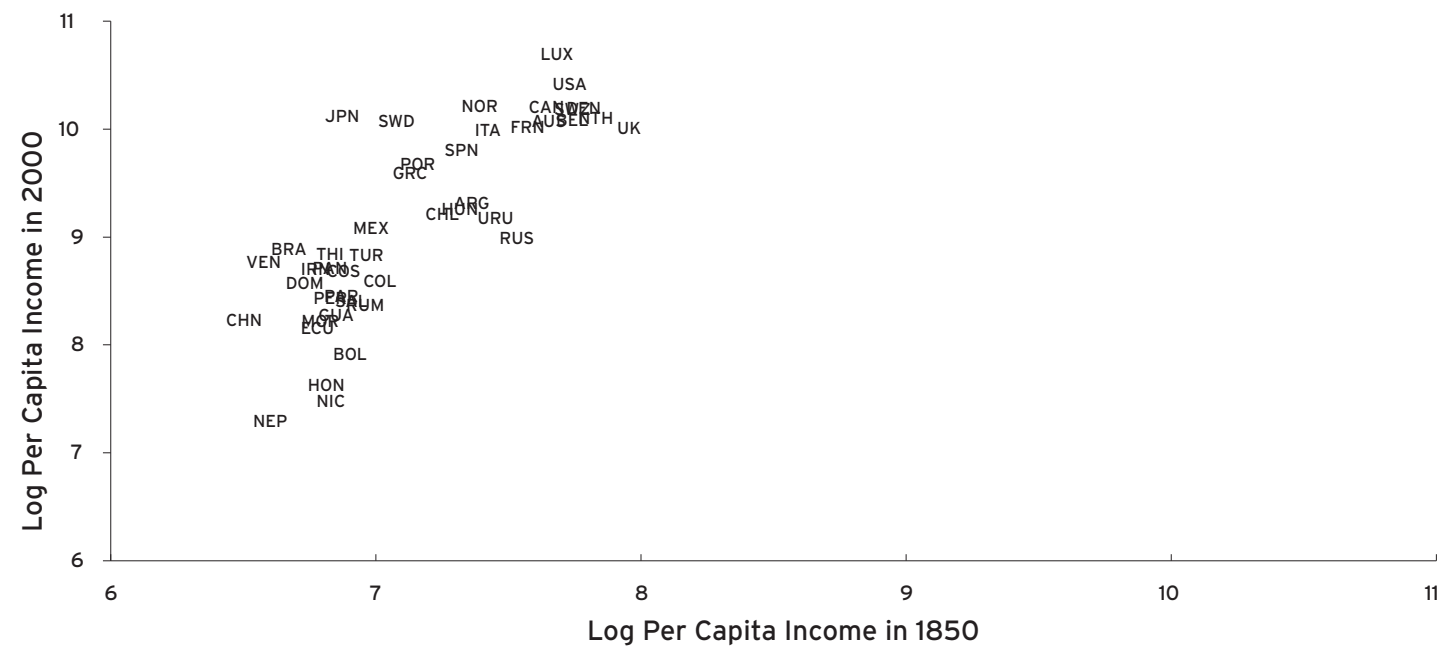


Figure 3. Polity Index of Democracy, 1850-2000

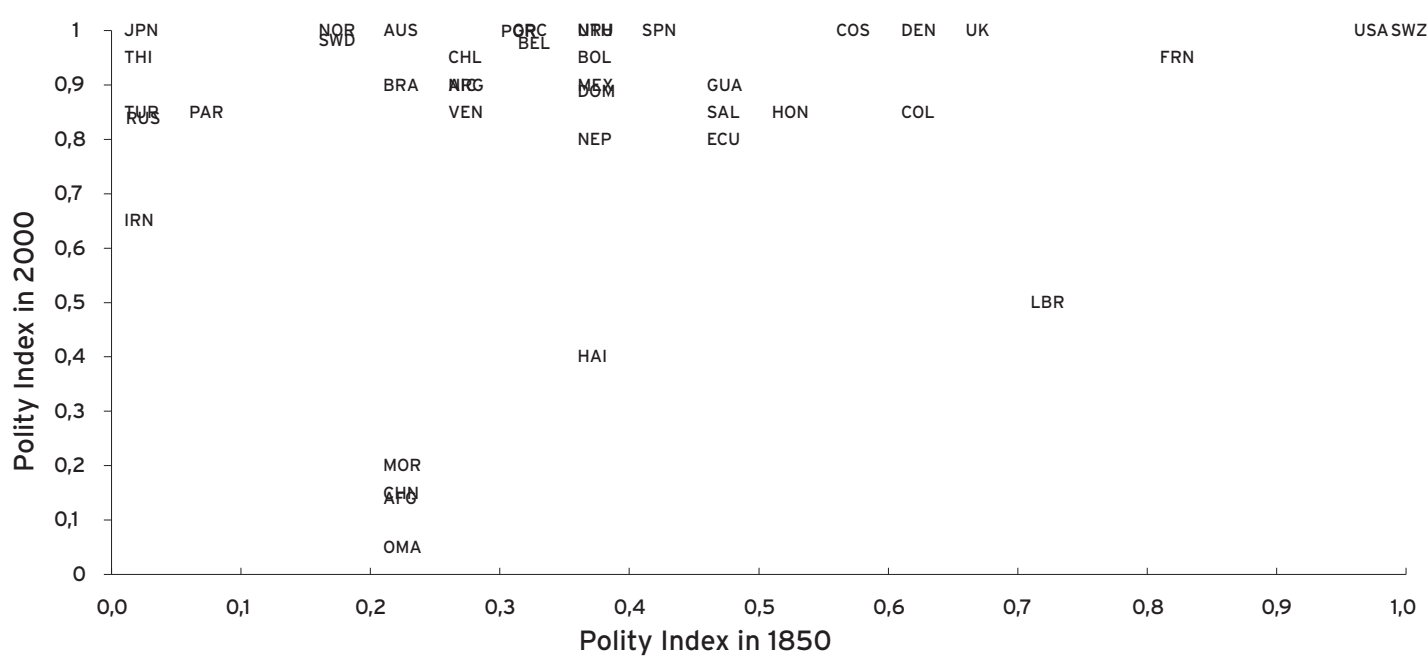

The need to look at the emergence of democracy before 1960 to assess the true impact of development on political regimes receives further confirmation from the data we have about the evolution of both income and democracy over a longer time frame. Figure 2 plots the relationship between income in 1850 and income in 2000 across countries. ${ }^{2}$ Figure 3 does the same thing for the level of democracy (using the continuous measure of Polity IV). Figure 2 shows a strong relationship between levels of development across time - the adjusted r-squared is 0.62 . Countries that were wealthier by mid-19th century continued to be ahead 150 years later. If anything, their economies had grown exponentially over time - leaving the poorest nations well behind (in relative terms). By contrast, Figure 3 reveals that no such relationship holds for politics - the adjusted r-squared is 0.01. Democratic institutions were absent or weak in almost all countries in the first half of the nineteenth century. It is not surprising then that, in the nineteenth century, that is, before the first democratization wave was in full swing, democracy and income were hardly correlated. Whatever structural or institutional factors (emerging at critical historical junctures) affected the level of development in 1850 (and continued to affect income in 2000) did not have the same effects on politics, that is, on the level of democracy, at that time. The adjusted r-squared for regressing democracy on income in 1870 was 0.10 (0.01 in 1850). However, by 1930 there was already considerable variation in the quality of democratic life across countries. And both variables had become substantially correlated: the adjusted r-squared for 1930 was 0.47 (0.41 in 1990).

Both the comparison between Figure 2 and Figure 3 and the growing correlation between income and democracy over time point toward a more complex relationship between economics and politics than the one described in Acemoglu et al. (2008). As already emphasized among several political economists and economic historians (North and Weingast 1989; North 1990; DeLong and Shleifer 1993; Putnam 1993; Engermann and Sokoloff 2002), it is likely that certain historical junctures (perhaps happening in

2. Per capita income is taken from Maddison (2003). 
the early modern era) resulted in different constellations of (both formal and informal) institutions across countries. Those different institutional configurations resulted in very different rates of economic growth (and of economic and social development) after the scientific revolution became fully embedded in the economy in the 18th and 19th centuries (Engerman and Sokoloff 2002, Mokyr 2002). The divergent institutional framework in place across countries did not shape representative institutions directly - again, democratic systems were absent in almost all countries throughout most of the 19th century. Instead, the effect of history and institutions on politics was presumably mediated by the processes of economic growth that have unfolded over the last two centuries. In other words, economic development triggered a set of social and institutional transformations (such as declining inequality, more diversified economies and so on) that contributed, in turn, to reshape the political landscape from mid-19th century onward.

\section{Re-testing the Modernization Hypothesis}

As pointed above, to test the 'modernization' theory, Acemoglu et al. (2008) examine the effect of per capita income on the level of democracy on yearly, 5-year, 10-year and 20-year periods during the period of 1960 to 2000 period and over one hundred countries. They complement that analysis with a test of a balanced panel on 25-year periods for 1875-2000 and about 25 countries. The test on the postwar period excludes the two first and crucial democratization waves shown in Figure 3. The 1875-2000 panel offers a very restricted sample - there are only 6 observations per country - and therefore very limited temporal variance.

An appropriate test must include a more fine-grained sample - maximizing the number of countries as well as its temporal dimension. This is done in Table 2. For the purposes of comparison, the first two columns of Table 1 reproduce the results of Acemoglu et al. (2008) for the five-year and ten-year data for the base sample of 1960-2000 (using the Polity measure of democracy). Columns 3 and 4 then estimate the impact of per capita income on democracy employing the sample of all sovereign countries from 1820 to 2000. The estimation procedures match those employed in Acemoglu et al. (2008): a standard pooled OLS regression in which the value of democracy is regressed on the lagged values of democracy and per capita income and where there is a full set of country dummies (to control for country-specific traits) as well as year dummies (to capture any common shocks to all countries). The Polity index of democracy, which ranges from -10 to 10 , has been here normalized from 0 to 1 . To maximize the number of observations, per capita income is based on Heston, Summers and Alden (2002) and Bourguignon and Morrisson (2002). ${ }^{3}$ Further robustness tests are done in Table 3 employing only the income data provided by Maddison (2003).

\footnotetext{
3. The postwar data for per capita income is taken from Heston, Summers and Alden (2002). The pre-World War Two data comes from Bourguignon and Morrisson (2002), who rely on Maddison (1995) to estimate per capita incomes. Both data sets have been merged after adjusting the BourguignonMorrisson data to make it comparable with the Heston-Summers-Alden data. Even before the adjustment both data sets are extremely well correlated: for the postwar period the correlation coefficient is 0.984 .
} 
Once the sample is expanded to encompass country-years that did experience the democratization take-off, the coefficient of per capita income becomes statistically significant in all models (columns 3 through 5). Consider model 4, based on 10-year data. From a substantive point of view, its coefficient of 0.124 implies that a 10-percent increase in per capita income should lead to a short-term increase of about 0.0124 in the democracy index (Column 4). Because we are controlling for the lagged value of democracy, it is more appropriate to consider the long-run effects of income on democracy: a 10-percent increase in per capita income (shown in the fifth row) translates into an increase of 0.02 in the index of democracy according to the results in column 4. Since GDP per capita has multiplied by more than a tenth-fold in developed countries in the last two centuries, development (at the scale it has seen throughout the contemporary era) seems to perform as a powerful factor in the general process of democratization (provided we give any causal value to these findings). Just doubling per capita income implies a shift of 0.2 points in a scale from 0 to $1 .{ }^{4}$

Table 2. Fixed Effects Results Using Polity Measure of Democracy

\begin{tabular}{|l|c|c|c|c|c|}
\hline & \multicolumn{2}{|c|}{$\begin{array}{c}1960-2000 \\
\text { (Acemoglu et al. 2008) }\end{array}$} & \multicolumn{3}{c|}{$1820-2000$} \\
\hline & Five-year & Ten-year & Five-year & Ten-year & Twenty-five-year \\
\hline \multirow{2}{*}{ Democracy t-1 } & $0.449 * * *$ & 0.060 & $0.660 * * *$ & $0.374 * * *$ & $0.255^{* * *}$ \\
\cline { 2 - 6 } & $(0.063)$ & $(0.091)$ & $(0.037)$ & $(0.060)$ & $(0.090)$ \\
\hline \multirow{2}{*}{ Log GDP per capita t-1 } & -0.006 & 0.007 & $0.036 * *$ & $0.124 * * *$ & $0.172 *$ \\
\cline { 2 - 6 } & $(0.039)$ & $(0.070)$ & $(0.018)$ & $(0.038)$ & $(0.98)$ \\
\hline Implied cumulative effect of income & -0.011 & 0.007 & 0.107 & 0.198 & 0.232 \\
\hline Observations & 854 & 419 & 2170 & 989 & 295 \\
\hline Countries & 136 & 114 & 154 & 148 & 86 \\
\hline R-squared & 0.82 & 0.77 & 0.81 & 0.66 & 0.58 \\
\hline
\end{tabular}

Fixed-effects OLS regressions with country dummies, time dummies and robust standard errors clustered by country in parentheses.

${ }^{* * *} \mathrm{p}<0.01 ;{ }^{* *} \mathrm{p}<0.05 ;{ }^{*} \mathrm{p}<0.10$; standard errors in parentheses

The implied cumulative effect of income represents the coefficient estimate of log GDP per capita $\mathrm{t}-1$ / (1 - democracy $\mathrm{t}-1)$.The dependent variable is the Polity index of democracy, normalized from 0 to 1. The sample is an unbalanced panel for 1960-2000 in Columns 1 and 2 and for 1820-2000 in Columns 3 through

\subsection{Robustness Tests and Instrumentation of Income}

Before examining the relation between development and democracy in more detail, Table 3 considers several new estimations to test for the robustness of the results. Column 1 reports the effects of per capita income employing income data taken from Maddison only. The effect is positive and in line with estimates of Table 1. Column 2 employs instead a dichotomous measure of democracy (taken from Boix-Rosato 2001) as the dependent variable. Although as a binary measure it is less fine-grained than the continuous Polity index, it avoids the measurement uncertainty (and, in fact, measurement error) that bedevils continuous measures such as Polity IV (particularly for 19th century observations). ${ }^{5}$ Per capita income continues to be a positive and statistically significant coefficient in all

4. Given a coefficient of lagged democracy of 0.374 (in column 4), the cumulative of a 100 percent increase in GDP per capita is $0.124 /(1-0.374)$ or about 0.198 .

For a statistical exploration and critique of consistency of the Polity index, see Treier and Jackman (2008). 
models. The long-run political effect of doubling per capita income fluctuates around 0.2 points. This is again considerable given the magnitude of the shift in incomes experienced by advanced nations since their take-off one century and a half ago. ${ }^{6}$

Table 3. Robustness Tests and Instrumented Effects of Income on Democracy.

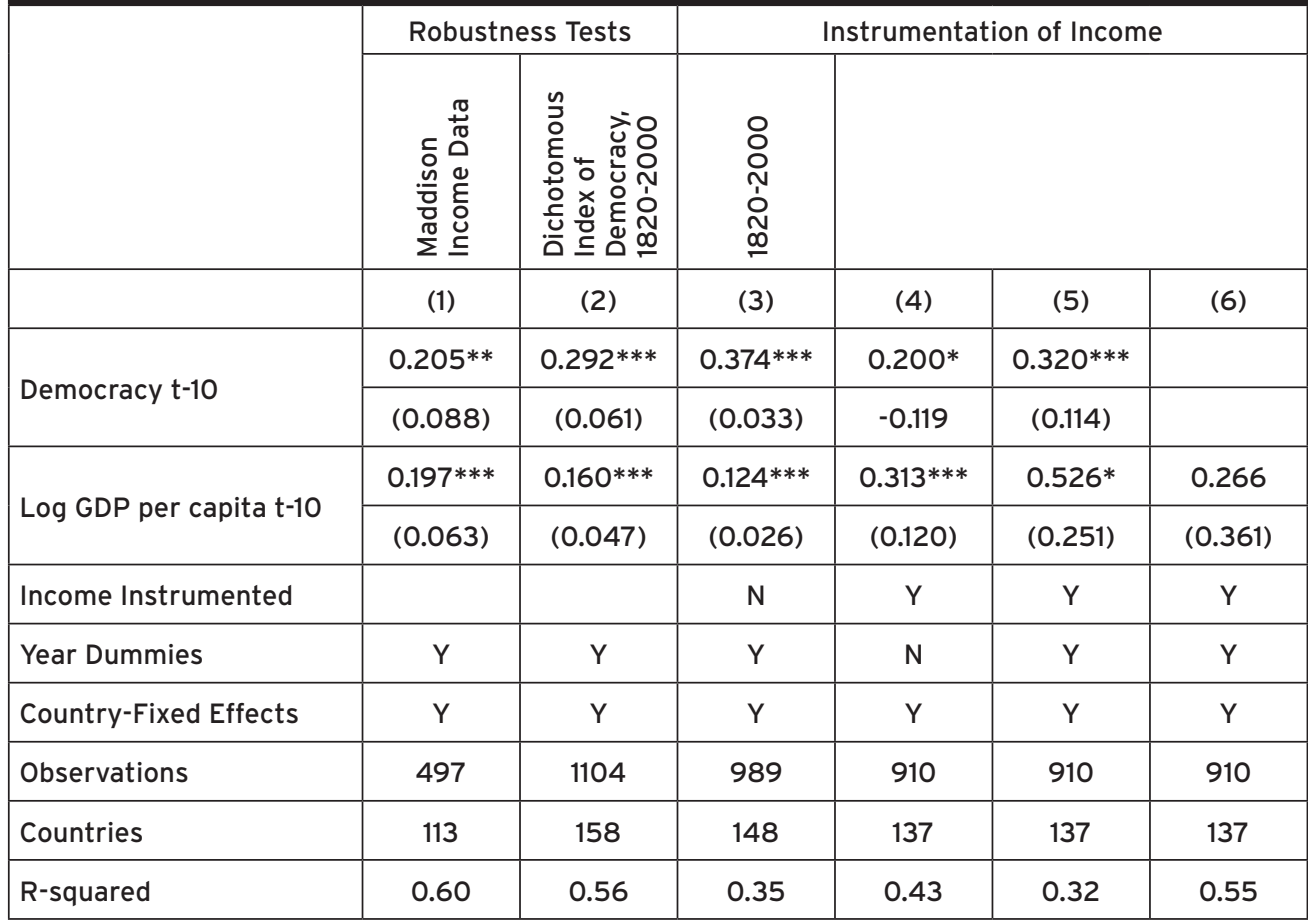

The dependent variable is the Polity index of democracy, normalized from 0 to 1, except in Column 2. Standard errors in parentheses

${ }^{* * *} \mathrm{p}<0.01,{ }^{* *} \mathrm{p}<0.05,{ }^{*} \mathrm{p}<0.1$

Columns 3 through 6 in Table 3 explore the causal relationship between income and democracy through the instrumentation of income. Acemoglu et al. (2008) employ two instruments for income: the savings rate and trade-shares between countries. Since data on saving rates is scarce before 1950, I rely here on trade data. More precisely, the instrument of income, $\hat{Y}_{\mathrm{it}-1,1}$ is a weighted sum of world income for each country $i$, with weights varying across countries as a function of their trade shares with other countries $j$ :

$$
\hat{Y}_{i t-1}=\sum_{j=1, j \neq i}^{N} \omega_{i j} Y_{j t-1}
$$

Where $\omega$ is the share of trade between country $i$ and country $j$ in the GDP of country i. Trade shares during the postwar period are calculated by employing IMF data on trade shares between 1980 and 1989. Trade shares for the period before 1940 are calculated employing data collected by Oneal-Russett (1999) on export dyads for the period 1900$1930 .^{7}$

\footnotetext{
Additional robustness tests not reported here include: balanced panels for 1870-2000, 1900-2000 and 1920-2000; and models with two lags of both income and the polity index. In all these tests, income continues to be positive and statistically significant.

The data compiled by Oneal and Russett is taken from bilateral trade data compiled by the League of Nations for the interwar period, complemented with data from The Statesman's Yearbook for the pre-World War I era.
} 
For the sake of comparison, column 3 in Table 3 reproduces the results in Table 1, column 4 - panel data with country and year dummies but no instrument for income. Column 2 then instruments for income and adds country-fixed effects. Column 3 adds year dummies (without the democracy lag). Finally, column 4 has the lagged variable and year and country dummies. (The first-stage estimation, not shown here, reports a strong relationship between instrument and income, with a t-statistic over 7.) Overall the coefficient of the instrumented variable is positive, stable and substantial in its size. Except for column 4, the instrumented variable is statistically significant and therefore income may be thought of as having a causal impact on the process of democratization.

\section{The Changing Impact of Income on Democracy}

In Section 3 we obtained two main results. On the one hand, income seems to have little or no effect on the level of democracy after World War Two, in line with recent work on democratization and development. On the other hand, once we examine the whole evolution of political institutions since 1800, that is, from the time the vast majority of countries were authoritarian to today, income matters to explain the process of democratization. I now turn to explore these two (seemingly contradictory) facts in more detail, that is, to examine why the impact of income on politics has varied over time.

\section{Table 4. The Effects of Income Over Time}

\begin{tabular}{|l|c|c|c|c|}
\hline & \multicolumn{4}{|c|}{ Effect of Per Capita Income by Periods } \\
\hline \multirow{2}{*}{ Democracy t-10 } & Before 1950 & After 1900 & After 1920 & After 1945 \\
\hline \multirow{2}{*}{ Log GDP per capita t-10 } & $0.412^{* * *}$ & $0.199 * * *$ & 0.077 & -0.086 \\
\cline { 2 - 5 } & $(0.083)$ & $(0.069)$ & $(0.082)$ & $(0.088)$ \\
\hline Observations & $0.111^{* *}$ & $0.121^{* *}$ & $0.148 * *$ & 0.084 \\
\hline Countries & $(0.045)$ & $(0.051)$ & $(0.063)$ & $(0.063)$ \\
\hline R-squared & 605 & 676 & 577 & 433 \\
\hline
\end{tabular}

Fixed-effects OLS regressions with country dummies, time dummies and robust standard errors clustered by country in parentheses. The dependent variable is the Polity index of democracy, normalized from 0 to 1 .

*** $\mathrm{p}<0.01$; ${ }^{* *} \mathrm{p}<0.05 ;{ }^{*} \mathrm{p}<0.10$; standard errors in parentheses

In joint test with all per capita income variable: $\wedge \wedge \wedge p>0.01, \wedge \wedge p>0.05$.

Before exploring the key sources of the conditional effect of income on democracy, Table 4 confirms the period-specific effects of income on democracy. It does so by reproducing the same estimations of Table 2 (column 4) while restricting the period of investigation gradually: column 1 looks at the period before 1950 (the time of the first democratization wave and its first partial reversal); column 2 
from 1900 to 2000; column 3 at 1920-2000; and column 4 at 1945-2000. ${ }^{8}$ As expected given our previous discussion on the historical process of democratization, the coefficient of per capita income becomes significant when we include the history of sovereign countries before World War Two (columns 1 through 3). Moreover, since from a substantive point of view the coefficient is slightly larger for the period 1920-2000, one may venture that development made a bigger impact during the interwar period. By contrast, and confirming Acemoglu et al. (2008)'s main result, per capita income does not explain within-country changes in political institutions after World War Two (column 4). In overall terms, therefore, Table 4 confirms, in conjunction with previous results in Section 3, the need to look at the whole story of democratization to understand the true impact of income and development on political institutions.

Table 5. Exploring the Effects of Income: Declining Marginal Effects and the International Order

\begin{tabular}{|c|c|c|c|c|c|}
\hline & \multicolumn{2}{|c|}{ Spline Model of Income } & \multicolumn{3}{|c|}{ The Impact of the International Order } \\
\hline & $1820-1950$ & $1820-2000$ & & & \\
\hline \multirow{2}{*}{ Democracy $\mathrm{t}-10$} & $0.410 * * *$ & $0.373 * * *$ & $0.374 * * *$ & $0.367 * * *$ & $0.362 * * *$ \\
\hline & $(0.081)$ & $(0.059)$ & $(0.060)$ & $(0.060)$ & $(0.060)$ \\
\hline \multirow{2}{*}{ Log GDP per capita t-10 } & $0.104 * *$ & $0.066^{\wedge \wedge \wedge}$ & $0.124 * * *$ & $0.119 * * *$ & \\
\hline & $(0.052)$ & $(0.051)$ & $(0.038)$ & $(0.039)$ & \\
\hline \multirow{2}{*}{$\begin{array}{l}\text { Log GDP per capita t-10 } \\
\text { (Over } \$ 3,000)\end{array}$} & $0.002^{\wedge \wedge}$ & $0.010 * *$ & & & \\
\hline & $(0.005)$ & $(0.004)$ & & & \\
\hline \multirow{2}{*}{$\begin{array}{l}\text { Log GDP per capita t-10 } \\
\text { (Over } \$ 6,000)\end{array}$} & $-0.005^{\wedge \wedge}$ & $0.005^{\wedge \wedge \wedge}$ & & & \\
\hline & $(0.003)$ & $(0.005)$ & & & \\
\hline \multirow{2}{*}{$\begin{array}{l}\text { Log GDP per capita t-10 } \\
\text { (Over } \$ 10,000)\end{array}$} & & $-0.006^{\wedge \wedge \wedge}$ & & & \\
\hline & & $(0.005)$ & & & \\
\hline \multirow{2}{*}{ International Order } & & & $0.052 * *$ & $0.055 * *$ & \\
\hline & & & $(0.021)$ & $(0.022)$ & \\
\hline \multirow{2}{*}{$\begin{array}{l}\text { Log GDP per capita t-10 } \\
\text { *Anti-democratic order }\end{array}$} & & & & & $0.113 * * *$ \\
\hline & & & & & $(0.038)$ \\
\hline \multirow{2}{*}{$\begin{array}{l}\text { Log GDP per capita t-10 } \\
\text { *Neutral democratic order }\end{array}$} & & & & & $0.109 * *$ \\
\hline & & & & & $(0.048)$ \\
\hline \multirow{2}{*}{$\begin{array}{l}\text { Log GDP per capita t-10 } \\
\text { *Pro-democratic order }\end{array}$} & & & & & $0.191 * * *$ \\
\hline & & & & & $(0.051)$ \\
\hline \multirow{2}{*}{ Soviet Occupation } & & & & $-0.188 * * *$ & $-0.192 * * *$ \\
\hline & & & & $(0.065)$ & $(0.062)$ \\
\hline Observations & 605 & 989 & 989 & 989 & 989 \\
\hline Countries & 79 & 148 & 148 & 148 & 148 \\
\hline R-squared & 0.69 & 0.67 & 0.66 & 0.66 & 0.66 \\
\hline
\end{tabular}

Fixed-effects OLS regressions with country dummies, time dummies and robust standard errors clustered by country in parentheses. The dependent variable is the Polity index of democracy, normalized from 0 to 1.

${ }^{* * *} \mathrm{p}<0.01$; ${ }^{* *} \mathrm{p}<0.05 ;{ }^{*} \mathrm{p}<0.10$; standard errors in parentheses

In joint test with all per capita income variable: ${ }^{\wedge \wedge \wedge} p>0.01, \wedge \wedge p>0.05$.

The conditional effect of income on democracy may be traced back to at least two main factors. The first one is strictly domestic. Even if we concede that income has a positive effect on the likelihood of democratization (and for reasons that I tackle later in Section 5), there is no reason why that effect should be linear. Transitions to democracy (or the stabilization of democratic institutions) may occur after a given country crosses a certain threshold. Yet, beyond that point, that is, after the country

8. For space considerations, I report results with 10-year lags. Results are robust to other lags. 
becomes fully democratic, income does not play any further role in promoting democracy - at most, more growth simply contributes to stabilize and consolidate liberal institutions. In other words, the marginal value of any additional growth becomes, from a political point of view, equal to zero.

With that in mind, columns 1 and 2 in Table 5 examine the varying effects of income at different stages of development through a spline function - below $\$ 3,000$, between $\$ 3,000$ and $\$ 6,000$, between $\$ 6,000$ and $\$ 10,000$ and above $\$ 10,000 .{ }^{9}$ Column 1 estimates the spline model for the period before 1950. It shows that development always increases the probability of democratization. Not surprisingly (given that most per capita incomes were under $\$ 4,000$ before World War Two), the coefficients for middle and upper income segments are not statistically significant. Column 2 estimates the spline model for the whole period from 1820 to 2000. Income matters for low levels of development - but it is only statistically significant in a joint test with the other income variables. For middle levels of development, per capita income accelerates that process. By contrast, the effects of per capita income wear off as development progresses beyond a certain threshold. For very high levels of per capita income, its impact turns out to be slightly negative. In a word, democratization happens at a certain point in the process of economic growth - mainly, it seems, as countries join the advanced core. After they do, there is no reason to expect that any further growth will translate into 'more' democracy.

That nonlinear effect of income on democracy can be linked to the temporal dimension shown in Table 4 in the following way. Up until the first half of the twentieth century, as (mainly European) countries became more developed, they transited to democracy (with a few reversions to authoritarianism). Once almost all wealthy countries became fully democratic after 1945, their continuous growth simply contributed to the consolidation of democratic rule - but it did not result in any change in the polity index. In turn, those countries that had not moved to democracy before 1950 had a hard time doing so: with a few exceptions, their growth rates remained low and, as a result, very few countries became fully developed countries (Quah 1996).

The second main source of the time-varying effect of income on democracy is the international order. From time immemorial, all great powers tend to approach (and interfere in) the domestic politics of their allies (and of the allies of their enemies) as a further means to advance their interests in the international arena. The War of the Peloponnese between Sparta and Athens was ignited by the disputes of opposing factions in the city of Corcyra. After the Napoleonic Wars, the members of the Holy Alliance intervened explicitly to suffocate any democratic revolutions across all Europe. During the Cold War, the Soviet Union and the United States maneuvered, directly or by proxy, to secure friendly administrations across the world. A quick look at Figure 1 reveals that democratic institutions often spread quickly

9. The income variables are defined as the corresponding per capita income above a given threshold and zero below. To choose thresholds for the estimation, I examined first the variation in the coefficient of interests for different per capita income segments through separate estimations. 
and in rather short periods of time: the early 1920s and the early 1990s. Similarly, many of their reversals were clustered in the 1930s and the late 1940s and early 1950s. All these transitions to and from democracy coincided with key shifts in the international system: the defeat of the Central Empires in 1918, the reemergence of Germany as a power under Hitler, the beginning of the Cold War and the collapse of the Soviet Union. Recent papers have shown, employing more systematic evidence, that the end of the Cold War had a considerable impact on the number, type and regional distribution of civil war onsets and revolutionary events (Boix 2008; Balcells and Kalyvas 2009) and on the introduction of semi-competitive elections in dictatorships (Levitsky and Way 2003; Boix and Svolik 2009). A similar story may be at work for democratic constitutions. The Cold War and the Soviet occupation damped the effect of income on democratic transitions. The fall of the Berlin wall was then likely to contribute to the rapid multiplication of democracies at the end of the twentieth century. ${ }^{10}$

Since measuring the direction and degree of intervention of each great power (as well as their strategic interaction) on the internal affairs of every country is extremely difficult (and probably impossible), I construct a variable that defines the overall structure of the international order every year as being anti-democratic, neutral to democracy or favorable to democracy as a function of the political leanings and general strategies of the existing great powers. ${ }^{11}$

I consider the international order as 'anti-democratic' when at least one of the great powers has an authoritarian government, espouses a political ideology contrary to the diffusion of democratic institutions and acts explicitly upon those principles in the international arena. In that international order the great powers structure their alliances along political ideologies - with absolutist monarchies cooperating with each other against liberal democracies or with democratic regimes allied against communist countries. The international system was 'anti-democratic' during the first half of the 19th century (until the great revolutions of 1848): the European central empires joined together to defeat France in the Napoleonic wars and then established the Holy Alliance to monitor the political and territorial status quo negotiated in the Congress of Vienna. It was also 'anti-democratic' from 1933 to 1942, with Nazi Germany as one of the main great powers intent on imposing its ideology in the European theater, and during the Cold War period (from 1948 to 1990).

In a 'neutral' international order, although the existing great powers differ in their constitutional structure (with at least one authoritarian state), authoritarian countries do not invest in the expansion of anti-liberal institutions. That 'ideological neutrality' (at least in the international sphere) implies that international alliances or conflicts do not follow ideological cleavages. Authoritarian and democratic great powers establish defensive pacts or alliances of mutual assistance for strict 'realpo-

10. On the impact of the Cold War through foreign aid see also Meernik et al. (1998) and Boschini and Olfsgård (2007).

11. The status of great power is defined following Mearsheimer (2001). 
litik' reasons, unconcerned about the political ideas and institutions of their allies. This type of system was in place from 1848 (as soon as the Holy Alliance was unable to quell the revolutionary explosions of that year) to 1918. During that period of time liberal England and Napoleon III's France allied against Russia in the 1850s; imperial France supported the liberal movement of Italian unification in the 1860s; Russia and England cooperated to abort a new war between France and Germany; and, starting at the turn of the century, the French Republic and the Russian czar struck a defensive pact against the central empires. Similarly, the cooperation of Soviet Russia and the United States against Hitler makes the period of 1942-47 a 'neutral' one.

Finally, an international order becomes 'democratic' if all the great powers are democratic - and do not take actions to sustain authoritarian regimes. ${ }^{12}$ This international system prevailed after World War One until the Wilsonian project collapsed and again after the breakdown of the Soviet Union.

Columns 3 through 5 in Table 5 examine the impact of the international order on the level of democracy. Since the likelihood that democratic institutions will be introduced or will survive should increase as the world moves from the anti-democratic to the pro-democratic order, I code the variable 'international order' as -1 for anti-democratic years (1800-1848, 1933-1942, 1948-1990), 0 for neutral years (18481917, 1942-1947) and 1 for pro-democracy periods (1918-1932, 1991-2000). Column 4 adds the variable "Soviet Occupation" that measures whether a country was occupied by the Soviet army or not.

In both models per capita income stills affects the likelihood of democracy significantly. But the international order has an effect of its own and in line with our expectations: democracy is more likely if all great powers are democratic. The effect of Soviet control is substantially negative: it reduces the level of democracy by almost 0.2 points (in a scale from 0 to 1 ).

Since the impact of income may differ depending on international conditions, Column 5 examines the effect of income separately for each type of international order. The coefficient of income turns out to be twice bigger in a pro-democracy international environment than in an antagonistic or neutral one. The unfavorable international climate that prevailed from the early 1930s until the late 1980s may explain why it took many middle-income countries much longer to adopt democracy even though they enjoyed an income level similar to those of European countries before 1920: whereas before World War Two three quarters of countries with a per capita over $\$ 3000$ (in constant dollars of 1985) were democratic, less than 40 percent above $\$ 3000$ were democratic during the Cold War period (Boix and Stokes 2003).

12. In the absence of authoritarian competitors, democracies may be interested in supporting democracies for the reasons outlined in democratic peace theory - arguably, that democracies do not fight among each other. See a critical review of that literature in Rosato (2003). 


\begin{tabular}{|c|c|c|c|c|c|c|c|c|}
\hline & \multicolumn{4}{|c|}{ Continuous Index of Democracy } & \multicolumn{4}{|c|}{ Dichotomous Index of Democracy } \\
\hline & 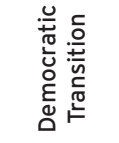 & 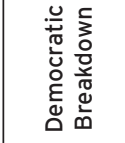 & 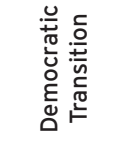 & 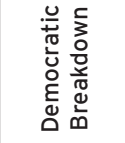 & 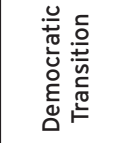 & 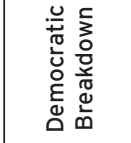 & 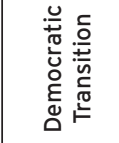 & 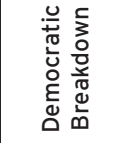 \\
\hline \multirow{2}{*}{ Democracy $\mathrm{t}-10$} & $0.657^{* * *}$ & $0.761^{* * *}$ & $0.649 * * *$ & $0.766^{* * *}$ & $0.573^{* * *}$ & $0.719 * * *$ & $0.575^{* * *}$ & $0.718^{* * *}$ \\
\hline & $(0.036)$ & $(0.034)$ & $(0.037)$ & $(0.035)$ & $(0.036)$ & $(0.042)$ & $(0.037)$ & $(0.042)$ \\
\hline \multirow{2}{*}{ Log GDP per cap. $t-10$} & $0.036^{\wedge \wedge \wedge}$ & $0.022^{\wedge \wedge \wedge}$ & & & $0.079^{\wedge \wedge \wedge}$ & $0.020^{\wedge \wedge \wedge}$ & & \\
\hline & $(0.034)$ & $(0.028)$ & & & $(0.059)$ & $(0.030)$ & & \\
\hline \multirow{2}{*}{$\begin{array}{l}\text { Log GDP per cap. } t-10 \\
\text { (Over } \$ 3,000)\end{array}$} & $0.007^{* *}$ & $0.003^{\wedge \wedge \wedge}$ & & & $0.013^{* *}$ & $0.004^{\wedge \wedge \wedge}$ & & \\
\hline & $(0.003)$ & $(0.003)$ & & & $(0.006)$ & $(0.006)$ & & \\
\hline \multirow{2}{*}{$\begin{array}{l}\text { Log GDP per cap. } t-10 \\
\text { (Over } \$ 6,000)\end{array}$} & $0.001^{\wedge \wedge \wedge}$ & $0.005^{\wedge \wedge \wedge}$ & & & -0.008 & $0.006^{\wedge \wedge \wedge}$ & & \\
\hline & $(0.004)$ & $(0.003)$ & & & $(0.006)$ & $(0.004)$ & & \\
\hline \multirow{2}{*}{$\begin{array}{l}\text { Log GDP per cap. } t-10 \\
\text { (Over } \$ 10,000)\end{array}$} & $-0.009 *$ & $0.003^{\wedge \wedge \wedge}$ & & & $-0.010 *$ & $0.004^{\wedge \wedge \wedge}$ & & \\
\hline & $(0.005)$ & $(0.002)$ & & & $(0.005)$ & $(0.003)$ & & \\
\hline \multirow{2}{*}{$\begin{array}{l}\text { Log GDP per cap. } \mathrm{t}-10 \\
\text { * Anti-democratic Intern. Order }\end{array}$} & & & $0.051^{*}$ & $0.060 * * *$ & & & $0.078^{* *}$ & $0.075^{* * *}$ \\
\hline & & & $(0.026)$ & $(0.017)$ & & & $(0.038)$ & $(0.021)$ \\
\hline \multirow{2}{*}{$\begin{array}{l}\text { Log GDP per cap. t-10 } \\
* \text { Neutral Intern. Order }\end{array}$} & & & $0.056^{*}$ & 0.041 & & & $0.131 * * *$ & 0.048 \\
\hline & & & $(0.033)$ & $(0.025)$ & & & $(0.049)$ & $(0.030)$ \\
\hline \multirow{2}{*}{$\begin{array}{l}\text { Log GDP per cap. } \mathrm{t}-10 \\
\text { * Pro-democratic Intern. Order }\end{array}$} & & & $0.106^{* * *}$ & $0.071^{* * *}$ & & & $0.234 * * *$ & $0.107^{* * *}$ \\
\hline & & & $(0.032)$ & $(0.027)$ & & & $(0.049)$ & $(0.029)$ \\
\hline Observations & 1034 & 1034 & 1034 & 1034 & 1123 & 1123 & 1123 & 1123 \\
\hline Countries & 150 & 150 & 150 & 150 & 158 & 158 & 158 & 158 \\
\hline$R$-squared & 0.83 & 0.88 & 0.82 & 0.87 & 0.73 & 0.85 & 0.73 & 0.85 \\
\hline
\end{tabular}

Fixed-effects OLS regressions with country dummies, time dummies and robust standard errors clustered by country in parentheses. ${ }^{* * *} \mathrm{p}<0.01 ;{ }^{* *} \mathrm{p}<0.05 ;{ }^{*} \mathrm{p}<0.10$; standard errors in parentheses

The bulk of the recent empirical literature on democratization looks at the effect of income on transitions to and from democracy rather than on levels of democracy. Accordingly, and with an eye on the potentially diminishing effects of income, Table 6 reports separate models of democratic transitions and democratic breakdowns. Columns 1 through 4 estimate those models employing the continuous index of Polity IV. In Columns 1 and 3, which estimate the impact of income on transitions to democracy, the value of the dependent variable is the maximum value of democracy at either time $t$ or time $t-1$ : this effectively restricts the analysis to those cases in which there has been an increase in democracy. In Columns 2 and 4 , which estimate the impact of income on transitions away from democracy, the value of the dependent variable is the minimum value of democracy at either time $\mathrm{t}$ or time $\mathrm{t}-1$ : this limits the analysis to those cases in which there has been a decline in the level of democracy. ${ }^{13}$

13. The standard estimations of political transitions (Przeworski and Limongi 1997; Boix and Stokes 2003; Epstein et al. 2006) employ nonlinear models to determine the effects of income. However, I here use linear models because nonlinear models do not generate consistent estimators in the presence of fixed effects. 
Columns 5 through 8 in Table reproduce the same analysis now employing the Boix-Rosato dichotomous democracy variable. Columns 5 and 7 look at transitions to democracy (the dependent variable takes the maximum value of democracy at times $\mathrm{t}$ and $\mathrm{t}-1$ ). Columns 6 and 8 examine the transitions away from democracy (the dependent variable is equated to the minimum value of democracy at times $t$ and $\mathrm{t}-1)$.

For each model (democratic transitions and democratic breakdowns) Table 6 considers first a spline model of income (Columns 1 and 2 and 5 and 6). It then considers the varying effect of income as a function of the prevailing international order (Columns 3 and 4 and 7 and 8). Higher levels of per capita income result in a higher probability of democratization - even after including country and time fixed-effects (Columns 1 and 5). However, those effects become flatter as countries go over $\$ 10,000$ (the coefficient becomes negative in the highest income segment). This captures the fact that once countries develop, they tend to transit to democracy - with the likely exception of a few cases (such as oil countries) that are wealthy yet impervious to change. In turn, Columns 2 and 6, which estimate the impact of income on democratic breakdowns, show that richer countries are less likely to experience reversals to authoritarian rule (a positive coefficient means a lower probability of democratic breakdown as per capita income increases) and that the effect of adding income has always a stabilizing impact on democracy.

Although the effect of income on democratic transitions is positive, its size is strongly affected by the international environment. In a world where the great powers are all democratic the effect of income is two times bigger than under other international conditions (Columns 3 and 7). In turn, income reduces the chances of a democratic breakdown (Columns 4 and 8 ) but there are no substantive differences across time periods. $^{14}$

\section{Income as a Proximate Cause?}

If development both makes a transition to democracy more likely, at least before World War II, and, once in place, it consolidates them, why is this so? Since its inception, the empirical literature on democratization has offered several causal mechanisms to account for the connection between income and democracy.

Lipset (1959) already saw development as the engine behind the gradual emergence of middle classes and the decline of social conflict, and therefore as the main event that triggered political liberalization. More recently, several models have for-

14. In estimations not shown here, per capita income ceases to be statistically significant as an explanatory variable of democratic transitions after World War Two but not before. In turn, per capita income does not explain democratic breakdowns before 1940 but it does afterwards. These results fit with those presented in Table 4. 
malized those claims in the context on an optimal taxation model with endogenous political institutions: there higher levels of income equality reduce the optimal tax of the median voter and therefore increase the incentives of wealthy individuals to accept democracy (instead of spending their resources to block it) (Boix 2003; Acemoglu and Robinson 2006). If incomes indeed become more equally distributed as countries develop, then one should not be surprised to find out that development generates and consolidates democracies. ${ }^{15}$ In addition to more equality, economic development has become associated (mostly after the industrial revolution) with a shift in the nature of wealth - from fixed assets (land) to mobile capital. As capital mobility increases, taxes must decline since capital holders can credibly threaten with exit (Hirschman 1981). Hence, under low levels of asset specificity the costs of democracy become sufficiently lower to convince wealthier voters (even under conditions of inequality) to accept liberal institutions. Notice that here the relationship between income and democracy is a conditional one: democracy emerges in countries with high returns to mobile capital (financial sectors, highly skilled population) but not in areas enjoying high incomes due to fixed capital (like oil) (Boix 2003).

The modernization literature has often but not exclusively cast the relationship between development and democracy in strict material or economic terms. Several researchers have claimed, instead, that development generates an increasingly more educated population. Education then fosters the values of political toleration and this makes democracy more likely (Lipset 1959; Huntington 1990; Welzel and Inglehart 2007).

Finally, we cannot discard the possibility that income may have a direct effect on levels of democracy as follows. Assume that the possibility that the marginal utility of additional income declines with income, with a structure $\mathrm{U}(\mathrm{yi})=(\mathrm{yi}) \alpha$ for $0<\alpha<1$. Whereas for low incomes, below or barely above the threshold of subsistence, each additional unit of income increases individual utility almost proportionally, at very high income levels the marginal utility of additional income approaches zero. Hence, as growth occurs and the per capita income of net tax payers rises, the disutility of supporting large transfer schemes (of the kind associated with democracies) becomes much lower than the costs of sustaining an authoritarian regime and democratic transitions become more likely.

Table 7 further probes the effects of development on political institutions by looking at the possible set of underlying factors that are shaped by (or are associated with) economic growth: economic inequality and the structure of the economy. To include all the political transitions of the second half of the nineteenth century and the first half of the twentieth century, Table 7 examines the correlates of democratic transitions and democratic stability using a data set that spans from 1850 to 2000.

\footnotetext{
15. Recent data collected by Deininger and Squire (1996) on income inequality, consisting in 692 comparable observations (587 of them with Gini coefficients) show that, at low levels of economic development, the degree of inequality is highly variable across countries. The correlation coefficient is -0.54 . For economies under a per capita income of $\$ 5,000$, the mean Gini index is 42.5 with the values ranging from 20.9 to 66.9 and a standard deviation of 10.4. But at higher levels of economic development, the occurrence of inequality diminishes. In economies with a per capita income of more than $\$ 10,000$ (constant prices of 1985), the average Gini index is 34.2 with a standard deviation of 3.6 .
} 
Columns 1 and 2 employ the polity index of continuous democratization. Columns 3 and 4 employ the Boix-Rosato dichotomous index. As in Table 7, the models of democratic transitions estimate positive increases in the indexes. The models of democratic breakdowns estimate downward changes in the indexes only.

Table 7. Income as a Proximate Cause of Democratic Transitions And Breakdowns, 1850-2000

\begin{tabular}{|c|c|c|c|c|}
\hline & \multicolumn{2}{|c|}{ Continuous Index of Democracy } & \multicolumn{2}{|c|}{ Dichotomous Index of Democracy } \\
\hline & $\begin{array}{l}\text { Transition to } \\
\text { Democracy }\end{array}$ & $\begin{array}{c}\text { Breakdown of } \\
\text { Democracy }\end{array}$ & $\begin{array}{l}\text { Transition to } \\
\text { Democracy }\end{array}$ & $\begin{array}{l}\text { Breakdown of } \\
\text { Democracy }\end{array}$ \\
\hline \multirow{2}{*}{ Democracy $\mathrm{t}-10$} & $0.586 * * *$ & $0.735^{* * *}$ & $0.560 * * *$ & $0.696 * * *$ \\
\hline & $(0.039)$ & $(0.036)$ & $(0.042)$ & $(0.046)$ \\
\hline \multirow{2}{*}{ Log GDP per capita $t-10$} & 0.055 & 0.035 & 0.026 & $0.060 *$ \\
\hline & $(0.037)$ & $(0.028)$ & $(0.051)$ & $(0.032)$ \\
\hline \multirow{2}{*}{$\begin{array}{l}\text { Proportion of Family } \\
\text { Farms t-10 }\end{array}$} & -0.007 & $0.138 * * *$ & $-0.184 *$ & $0.177^{* * *}$ \\
\hline & $(0.073)$ & $(0.05)$ & $(0.100)$ & $(0.057)$ \\
\hline \multirow{2}{*}{ Index of Human Capital t-10 } & $0.350 * * *$ & -0.111 & $0.526 * * *$ & 0.001 \\
\hline & $(0.120)$ & $(0.118)$ & $(0.200)$ & $(0.113)$ \\
\hline \multirow{2}{*}{$\begin{array}{l}\text { Proportion of Population } \\
\text { in Non-Agrarian Sector } t-10\end{array}$} & -0.209 & 0.219 & 0.049 & 0.199 \\
\hline & $(0.178)$ & $(0.140)$ & $(0.264)$ & $(0.202)$ \\
\hline \multirow{2}{*}{ Soviet Occupation } & $-0.243 * * *$ & -0.008 & $-0.339 * * *$ & -0.015 \\
\hline & $(0.048)$ & $(0.033)$ & $(0.078)$ & $(0.038)$ \\
\hline \multirow{2}{*}{ International Order } & -0.024 & 0.019 & -0.035 & $0.047^{*}$ \\
\hline & $(0.027)$ & $(0.375)$ & $(0.043)$ & $(0.025)$ \\
\hline Observations & 806 & 806 & 852 & 852 \\
\hline Countries & 132 & 132 & 137 & 137 \\
\hline R-squared & 0.80 & 0.87 & 0.75 & 0.83 \\
\hline
\end{tabular}

Fixed-effects OLS regressions with country dummies, time dummies and robust standard errors clustered by country in parentheses.

${ }^{* * *} \mathrm{p}<0.01 ;{ }^{* *} \mathrm{p}<0.05 ;{ }^{*} \mathrm{p}<0.10$; standard errors in parentheses

Since data on income inequality are practically non-existent for any country before World War II, Table 7 relies on two indicators to proxy the extent of economic inequality: the distribution of agricultural property ${ }^{16}$ and the quality of human capital. ${ }^{17}$ Both variables track economic inequality relatively well. For the period after 1950, the correlation coefficient between the Gini index of economic inequality (excluding socialist economies) and the percentage of family farms is -0.66 . For countries with a per capita income below $\$ 2,000$ the correlation coefficient is -0.75 . The coefficient of correlation of the index of education and the Gini index reported by Deininger and Squire (1996) is -0.59. To measure the structure of the economy, that is, the predominant type of wealth, Table 7 relies on the proportion of the population employed in non-agricultural occupations. The indices of family farms, human capital and

16. The distribution of agricultural property is measured by the area of family farms as a percentage of the total area of holdings. This measure, gathered and reported by Vanhanen, defines family farms as those "that provide employment for not more than four people, including family members, [...] that are cultivated by the holder family itself and [...] that are owned by the cultivator family or held in ownerlike possession" (Vanhannen 1997: 48). This definition, which aims at distinguishing family farms from large farms cultivated mainly by hired workers, is not dependent on the actual size of the farm - the size of the farm varies with the type of product and the agricultural technology used. The percentage of family farms captures the degree of concentration and therefore inequality in the ownership of land. It varies from countries with 0 percent of family farms to nations where 94 percent of the agricultural land is owned in family farms; the mean of the sample is 30 percent with a standard deviation of 23 percent.

17. To measure the level of human capital, I rely on Vanhanen's "index of knowledge distribution", which consists in the arithmetic mean of the percentage of literates in the adult population and the 'level of students'. The level of students is the number of students per 100,000 inhabitants, normalized so that 1,000 students per 100,000 inhabitants corresponds to a level of 100 percent. 
non-agrarian employment have been normalized from 0 to 1 . All models include the log of per capita income as well as country and year dummies. Finally, all estimations include two variables measuring the international system: an annual one coding the international system as anti-democratic, neutral or pro-democratic; and another one specifying whether the country is under the control of the Soviet army or not.

Notice, in the first place, that, although the coefficient of per capita income remains positive, it declines in size and loses statistical significance in all models but the last one. This finding probably points to the fact that per capita income, as employed in the modernization literature in postwar samples, behaves mostly as a proxy for other more fundamental factors.

Generally speaking, underlying social and economic conditions (associated with the process of development) matter for democratization. However, it is worth noting that the causes of democratic transitions and of democratic breakdowns are partly different. Democratic transitions are more likely to occur in countries with higher levels of human capital (Columns 1 and 3). Given that the dependent variable ranges from 0 to 1 , the effect is very substantive: 0.35 in the continuous polity index and 0.53 in the dichotomous one.

In turn, democratic breakdowns are mostly conditioned by the distribution of assets in the agrarian world. A higher proportion of family farms reduces the probability that a democratic country will revert to authoritarian rule: the coefficient is close to 0.14 in Column 2 and 0.18 in Column 4. (Remember that in these models a positive coefficient means that an authoritarian regime is less likely to take place.) In other words, in an agrarian economy the probability of a democratic breakdown falls to 0 as one moves from concentrated land ownership (as in countries such as Russia before the Stolypin reforms and the Soviet Revolution, Spain for most of the 20th-century, and most Latin American nations) to the highly fragmented property systems (as in countries such as Norway, the United States, and Canada, where family farms represented three- to four-fifths of all land) at the turn of the 20th century. The probability of a democratic breakdown also declines with the industrialization of the economy: the coefficient of the proportion of non-agrarian employment is 0.219 and very close to statistical significance $(\mathrm{p}=0.123)$ in Column 2.

In line with previous results in Table 6, international factors matter to explain democratic transitions. The dummy variable "Soviet occupation" is statistically significant and it is associated with a reduction of 0.24 points in the movement toward more democratic institutions (and of 0.34 employing the dichotomous variable in Column 3). Again this finding may certainly contribute to explain why models that estimate the effect of development in the postwar period find that income behaves so poorly. The type of general international system only explains democratic breakdowns in Column 4: a more pro-democratic environment reduces their occurrence. 


\section{Conclusions}

In the last fifty years, the research agenda on democratization has been dominated by a prolonged debate over the impact of development on political institutions. Improving the estimation strategies of previous statistical models, recent research has claimed that per capita income has no effect on democracy. However, the result is only valid if we limit our analysis to the postwar period. It is not when we include in our tests the first two (crucial) waves of democratization that took place before World War Two. Once we exploit the full variance of a panel that runs from early nineteenth century to the end of the twentieth century, per capita income turns to be statistically associated with the process of democratization, even after controlling for country and year effects and after subjecting the estimations to several robustness tests. The instrumentation of income (using trade-weighted world income) also points to the causal effect of development on political regime.

The results of this paper suggest, in conjunction with all the existing work on democracy and economic development, the following, more plausible, theoretical interpretation of the historical patterns I just discussed. Those countries that (as a result of their particular domestic conditions) experienced sustained growth after 1800 witnessed key changes in their social structures. In turn, those transformations gradually put in place the underlying conditions that made the transition to a stable democratic regime feasible. In fact, already in his seminal paper of 1959 on development and democracy, Lipset was keenly aware of the strengths and limitations of looking at the relationship between development (and per capita income) and democracy. To show that per capita income is associated with democratization, he warned, does not settle how this association operates. The forefather of modernization theory saw the level of per capita income simply as a good proxy for certain, deeper social and economic transformations. Indeed, per capita income seems to be a proxy for a process of development that brought about central changes in the distribution and the nature of wealth (and perhaps in the beliefs of actors) thus making democracy a stable political outcome.

The impact of developmental conditions on the nature of political institutions is probably not linear. Higher levels of development stabilize democracies - but logically do not democratize any further fully democratic polities. More important, their impact has been partially affected by the overall international order in place. Liberal institutions flourished with the Wilsonian arrangements of 1918 and after the fall of the Berlin wall but they collapsed during under the Holy Alliance and the Cold War. That should account for the historical patterns of democratization waves and of cycles of institutional diffusion the world has witnessed so far. 


\section{References}

Acemoglu, Daron, Simon Johnson, James E. Robinson and Pierre Yared. 2008. Income and Democracy. American Economic Review, 98 (June): 808-842.

Barro, Robert J. 1999. Determinants of Democracy. Journal of Political Economy, 107 (6): 158-183.

Boix, Carles. 2003. Democracy and Redistribution. New York: Cambridge University Press.

Boix, Carles. 2008. Economic Roots of Civil Wars and Revolutions in the Contemporary World. World Politics, 60 (April): 390-437.

Boix, Carles and Sebastian Rosato. 2001. A Complete Data Set of Political Regimes, 18001999. Department of Political Science, The University of Chicago, Chicago.

Boix, Carles and S. Stokes. 2003. Endogenous Democratization. World Politics, 55 (July): 517-549.

Boschini, Anne and Anders Olfsgård. 2007. Foreign Aid: An Instrument for Fighting Communism?. Journal of Development Economics, 43 (May): 622-648.

Bourguignon, François and Morrisson, Christian. 2002. Inequality Among World Citizens: 1820-1992. American Economic Review, 92: 727-744.

Dahl, Robert. 1971. Polyarchy: Participation and Opposition. New Haven, Connecticut: Yale University Press.

Deininger, Klaus and Lyn Squire. 1996. A New Data Set Measuring Income Inequality. World Bank Economic Review, 19 (September).

DeLong, Bradford J. and Andrei Shleifer. 1993. Princes and Merchants: European City Growth before the Industrial Revolution. Journal of Law and Economics, 36 (October): 671-702.

Engerman, Stanley L. and Sokoloff, Kenneth L. 2002. Factor Endowments, Inequality, and Paths of Development among New World Economies. Economia, 3: 41-102.

Epstein, David L. Robert Bates, Jack Goldstone, Ida Kristensen and Sharyn O'Halloran. 2006. Democratic Transitions. American Journal of Political Science, 50 (July): 551:569.

Geddes, Barbara. 2007. What Causes Democratization? In Carles Boix and Susan Stokes (ed.) The Oxford Handbook of Comparative Politics. Chapter 14. New York: Oxford University Press.

Heston, Alan, Robert Summers and Bettina Aten. 2002. Penn World Table Version 6.1. Center for International Comparisons at the University of Pennsylvania (CICUP).

Huntington, Samuel P. 1990. The Third Wave: Democratization in the Late Twentieth Century. Norman: University of Oklahoma Press.

Kalyvas, Stathis and Laia Balcells. 2009. International System and Technologies of Rebellion: How the Cold War Shaped Internal Conflict. Working paper, Yale University.

Levitsky, Steven and Lucan A. Way. 2003. Autocracy by Democratic Rules: The Dynamics of Competitive Autoritarianism in the Post-Cold War Era. Unpublished manuscript, Harvard University.

Lipset, Seymour M. 1959. Some Social Requisites of Democracy: Economic Development and Political Legitimacy. American Political Science Review, 53: 69-105.

Maddison, Angus. 2003. The World Economy: Historical Statistics. Paris: OECD.

Mearsheimer, John J. 2001. The Tragedy of Great Power Politics. New York: Norton. 
Meernik, James, Eric L. Krueger and Steven C. Poe. 1998. Testing Models of U.S. Foreign Policy: Foreign Aid during and after the Cold War. The Journal of Politics, 60 (February): 63-85.

Mokyr, Joel. 2002. The Gift of Athena. Princeton, NJ: Princeton University Press.

Moore, Barrington. 1966. Social Origins of Dictatorship and Democracy : Lord and Peasant in the Making of the Modern World. Boston: Beacon Press.

North, Douglass C.1990. Institutions, Institutional Change and Economic Performance. Cambridge: Cambridge University Press.

North, Douglass C. And Barry R. Weingast, 1989. Constitutions and Commitment: The Evolution of Institutional Governing Public Choice in Seventeenth-Century England. The Journal of Economic History, 49 (December): 803-832.

O'Donnell, Guillermo A. 1973. Modernization and Bureaucratic-Authoritarianism: Studies in South American Politics. Berkeley: University of California Press.

Oneal, John R. and Bruce Russett. 1999. The Kantian Peace: The Pacific Benefits of Democracy, Interdependence, and International Organizations, 1885-1992. World Politics, 52 (April): 1-37.

Przeworski, Adam and Fernando Limongi. 1997. Modernization: Theories and Facts. World Politics, 49 (January).

Przeworski Adam, José Cheibub and Fernando Limongi. 2000. Democracy and Development. New York: Cambridge University Press.

Putnam, Robert. 1993. Making Democracy Work. Princeton, NJ: Princeton University Press.

Quah, Danny T.1996. Twin Peaks: Growth and Convergence in Models of Distributional Dynamics. Economic Journal, 106: 1045-1055.

Rosato, Sebastian. 2003. The Flawed Logic of Democratic Peace Theory. American Political Science Review, 97 (4): 585-602.

Treier, Shawn and Simon Jackman. 2008. Democracy as a Latent Variable. American Journal of Political Science, 52 (January): 201-217.

Vanhanen, Tatu. 1997. Prospects of Democracy: A Study of 172 Countries. London: Routledge.

Welzel, Christian and Ronald Inglehart. 2007. Mass Beliefs and Democratic Institutions. In Carles Boix and Susan Stokes (ed.) The Oxford Handbook of Comparative Politics, Chapter 13. New York: Oxford University Press. 